\title{
BAHAN AJAR ELEKTRONIK BERBASIS STEM UNTUK BLENDED LEARNING PADA MATERI FLUIDA SMA
}

\author{
Yetti Supriyatia ${ }^{\text {a) }}$ A. Handjoko Permana ${ }^{\text {b) }}$, Novia Dwi Safira Aziz ${ }^{\text {c) }}$ \\ Program Studi Pendidikan Fisika, Fakultas Matematika dan Ilmu Pengetahuan Alam, Universitas Negeri \\ Jakarta, Jl. Rawamangun Muka No.1, Jakarta Timur, 13220, Indonesia \\ Email: a)y_supriyati@yahoo.com, b)handjoko@unj.ac.id, ${ }^{c}$ noviadwi606@gmail.com
}

\begin{abstract}
Abstrak
Masih diperlukannya tatap muka antara guru dan siswa disamping pembelajaran online membuat pembelajaran secara blended learning banyak dipakai saat ini. Penelitian ini bertujuan untuk mengembangkan bahan ajar elektronik berbasis STEM yang digunakan untuk pembelajaran secara blended learning. Metode yang digunakan dalam penelitian ini adalah metode research and development (RnD) dengan model pengembangan ADDIE. Model pengembangan ADDIE meliputi lima tahapan, yaitu tahap analisis (Analyze), tahap perencanaan (Design), tahap pengembangan (Development), tahap implementasi (Implementation), dan tahap evaluasi (Evaluation). Bahan ajar elektronik ini dikembangkan berbasis STEM. Konten dari bahan ajar ini terdiri dari kompetensi, materi, lembar kerja peserta didik untuk praktikum, tugas projek, diskusi, dan kuis. Pada bahan ajar elektronik ini juga dilengkapi dengan gambar, animasi, simulasi, praktikum virtual, dan video. Bahan ajar yang dihasilkan divalidasi oleh ahli materi, ahli media, ahli pembelajaran, menggunakan kuesioner dengan skala Likert. Selanjutnya dilakukan uji keterbacaan oleh beberapa guru dan siswa.
\end{abstract}

Kata-kata kunci: bahan ajar, STEM, blended learning, fluida.

\begin{abstract}
Face-to-face learning between teachers and students, besides online learning, is still needed makes blended learning widely used today. This research aims to develop STEM-based electronic teaching materials that are used for blended learning. The research method used is the research and development $(\mathrm{R} \& \mathrm{D})$ method with the ADDIE development model. The ADDIE development model includes five stages. There is the analysis stage (Analyze), the planning stage (Design), the development stage (Development), the implementation (Implementation), and the evaluation stage (Evaluation). This electronic teaching material was developed based on STEM. This teaching material's content consists of competencies, material, student worksheets for practicum, project assignments, discussions, and quizzes. The electronic teaching materials are also equipped with pictures, animations, simulations, virtual practicums, and videos. Teaching materials produced validated by material experts, media experts, learning experts, using a questionnaire with a Likert scale and product trials by teachers and students.
\end{abstract}

Keywords: teaching material, STEM, blended learning, fluid. 


\section{PENDAHULUAN}

Dalam upaya meningkatkan kualitas pendidikan Indonesia, pemerintah menyempurnakan kurikulum 2013 menjadi kurikulum 2013 revisi [1]. Kurikulum 2013 revisi pada implementasinya dalam pembelajaran fisika disekolah menuntut siswa untuk membangun pengetahuannya secara mandiri. Penemuan konsep fisika dilakukan secara mandiri oleh siswa dan guru berperan sebagai fasilitator [2]. Untuk menunjang proses pembelajaran kurikulum 2013 revisi maka diperlukan bahan ajar yang dapat dengan mudah dipahami sendiri oleh siswa. Salah satu jenis bahan ajar adalah bahan ajar elektronik. Bahan ajar elektronik adalah bahan ajar yang isi materialnya dikemas dalam interaktif multimedia [3]. Bahan ajar interaktif pada pembelajaran fisika diantaranya Augmented Reality [4], simulasi laboratorium virtual [5], ujian berbasis flash [6], dan video tracker [7]. Pesatnya perkembangan teknologi di dunia pendidikan menjadikan bahan ajar untuk blended learning sebagai bahan ajar yang tepat diterapkan kepada siswa abad 21 [8].

Blended learning adalah pembelajaran yang menggabungkan pengunaan sumber belajar online seperti web/blog dan pembelajaran secara tatap muka. Tujuan pelaksaanaan dari blended learning adalah untuk mendapat pembelajaran yang "paling baik" dengan menggabungkan keunggulan dari metode konvensional yang memungkinkan pembelajaran secara interaktif dan metode online yang memberikan materi secara online tanpa batasan ruang dan waktu sehingga dapat dicapai pembelajaran yang maksimal [9].

Blended learning pada umumnya adalah kombinasi yang tepat dalam pemilihan dan penentuan metode serta tool dan teknologi yang relevan dalam seting belajar sinkronous dan asinkronous sesuai dengan kompetensi yang ingin dicapai siswa. Secara mendasar terdapat tiga tahapan dasar dalam model blended learning yang mengacu pembelajaran berbasis ICT, yakni: (1) seeking of information, (2) acquisition of information, dan (3) synthesizing of knowledge.

Bahan ajar elektronik juga perlu dikembangan dengan suatu pendekatan agar lebih terstruktur dan terarah [10]. Pemilihan pendekatan pembelajaran STEM sesuai untuk pendidikan di Indonesia khususnya untuk pelajaran fisika [11]. Pendekatan STEM memiliki potensi untuk mendukung siswa dalam mengembangkan kemampuan seperti menyelesaikan masalah, komunikasi, dan keterampilan kolaborasi [12]. Sebagian besar penerapan STEM memiliki dampak positif terhadap motivasi dan keterlibatan siswa dalam kegiatan pembelajaran sains dan teknik [13]. Pendidikan STEM ini juga mempengaruhi dalam afektif siswa yang menunjukkan perubahan sikap dan kepercayaan diri siswa saat pembelajaran [14].

Karakteristik utama dalam integrasi pendekatan STEM dalam implementasi kurikulum 2013 adalah keterpaduaan/ integerasi sains, teknologi, enjiniring dan matematika dalam memecahkan masalah di kehidupan nyata [15]. Penyajian pembelajaran dengan pendekatan STEM harus memenuhi beberapa aspek dalam Scientific \& Engineering Practice, juga menggambarkan adanya Crosscutting Concept atau irisan konsep di antara pengetahuan sains, teknologi, rekayasa/enjiniring dan matematika. Selain itu pada pembelajaran berbasis STEM, salah satu karakteristik yang harus terlihat dalam proses pembelajaran adalah proses desain rekayasa atau Engineering Design Process (EDP).

Materi fluida dipilih karena siswa masih mengalami kesulitan dalam memahami konsep fluida. Materi fluida memiliki karakteristik analisis konseptual yang menuntut siswa untuk mengaitkan konsep fisika dengan fenomena alam sehingga siswa diharapkan dapat bernalar dan berpikir hingga mengaplikasikannya dalam kehidupan sehari-hari [16]. Pada materi fluida siswa mengetahui persamaan yang terkait dengan keadaan benda terapung dan tenggelam, namun apabila dihadapkan pada persoalan yang berkaitan dengan konsep tersebut, siwa masih mengalam kebingungan dan tidak tepat dalam menerapkan persamaan tersebut [17].

Oleh karena itu, bahan ajar elektonik ini dikembangkan dengan tujuan menarik perhatian dan minat siswa serta memudahkan untuk mempelajari fisika sehingga dapat meningkatkan pencapaian hasil belajar siswa. 


\section{METODOLOGI}

Metode penelitian yang digunakan pada pengembangan blended leraning kali ini adalah metode research and development atau penelitian pengembangan dengan menggunakan model pengembangan ADDIE [18]. Model pengembangan ADDIE menjelaskan model desain pembelajaran lima langkah untuk menciptakan instruksi yang efektif yaitu Analisis (Analysis), Desain (Design), Pengembangan (Development), Implementasi (Implementation), dan Evaluasi (Evaluation). Komponen yang dibuat dengan mengikuti model ADDIE dapat digunakan di lingkungan apa pun baik saat online atau tatap muka [19].

\section{Tahap analisis}

Dalam langkah ini peneliti melakukan analisis kebutuhan kepada peserta didik kelas XI SMAN 50 Jakarta mengenai kebutuhan bahan ajar pada proses pembelajaran. Berdasarkan hasil analisis kebutuhan disimpulkan bahwa peserta didik membutuhkan bahan ajar yang interaktif untuk menunjang dalam memahami materi fisika. Selain itu berdasarkan analisis kebutuhan juga dapat disimpulkan bahwa penggunaan bahan ajar elektronik sesuai dengan karakteristik peserta didik karena lebih dari $90 \%$ setiap harinya siswa menggunakan smartphone dan internet. Dalam penelitian ini, peneliti mengembangkan bahan ajar elektronik pada materi fluida sehingga peneliti juga melakukan analisis materi. Materi fluida terdiri dari fluida statis dan dinamis terdapat dalam Kompetensi Dasar Mata Pelajaran Fisika tingkat SMA kelas XI.

Berdasarkan Permendikbud Nomor 37 Tahun 2018 kompetensi dasar fisika SMA/MA adalah sebagai berikut :

Fluida statis

3.3.Menerapkan hukum-hukum fluida statik dalam kehidupan sehari-hari

4.3.Merancang dan melakukan percobaan yang memanfaatkan sifat-sifat fluida statik, berikut presentasi hasil percobaan dan pemanfaatannya

Fluida dinamis

3.4. Menerapkan prinsip fluida dinamik dalam teknologi

4.4. Membuat dan menguji proyek sederhana yang menerapkan prinsip dinamika fluida

\section{Tahap desain}

Pada tahap ini dilakukan penyusunan rancangan konten dari bahan ajar elektronik berbasis STEM untuk blended learning pada materi fluida. Selain itu pada tahap ini juga dilakukan penyusunan instrument penelitian berupa angket dengan skala likert. Instrumen penelitian digunakan untuk menilai kualitas kelayakan bahan ajar elektronik yang dikembangan. Penilaian terhadap produk dilakukan oleh ahli materi, ahli media, ahli pembelajaran, guru dan siswa SMA.

\section{Tahap pengembangan}

Pada tahap ini dilakukan realisasi rancangan produk yaitu membuat bahan ajar elektronik berbasis STEM untuk blended learning pada materi fluida. Pembuatan bahan ajar elektronik menggunakan smart apps creator dan hasil outputnya berupa aplikasi android. Pada tahap pengembangan ini juga dilakuan evaluasi atau uji kelayakan produk. Uji kelayakan dilakukan oleh ahli media, ahli pembelajaran, dan ahli materi. Produk dinyatakan layak berdasarkan interpretasi skor yang didapakan menggunakan skala likert.

\section{Tahap implementasi}

Pada langkah ini dilakukan uji keterbacaan oleh guru fisika SMA. Selain itu juga dilakukan uji coba kepada siswa kelas XI SMA. Uji coba dilakukan dengan melakukan proses pembelajaran blended learning menggunakan bahan ajar elektonik yang telah dikembangkan. 


\section{Tahap evaluasi}

Setiap tahap dalam proses ADDIE melibatkan evaluasi formatif. Dalam penelitian ini evaluasi dilakukan pada tahap analisis, desain, pengembangan, dan pada tahap implementasi dilakukan evaluasi dengan bantuan peserta didik dan guru.

\section{HASIL DAN PEMBAHASAN}

Hasil dari penelitian ini adalah bahan ajar elektronik berbasis STEM berupa aplikasi android pada materi fluida yang dapat digunakan dalam blended learning. Komponen bahan ajar elektronik ini terdiri dari kompetensi, materi, praktikum, tugas projek, latihan soal, evaluasi, serta petunjuk belajar guru dan siswa. Konten dari bahan ajar elektronik ini juga dikembangkan dengan pendekatan STEM yang meliputi aspek sains, technology, engineering, dan mathematics. Penelitian ini masih pada tahap pengembangan. Setelah peneliti melakukan analisis kebutuhan, membuat rancangan desain aplikasi, selanjutnya peneliti melakukan tahap pengembangan. Dibawah ini adalah tampilan bahan ajar elektronik dalam bentuk aplikasi android.

TABEL 1. Komponen bahan ajar elektronik.

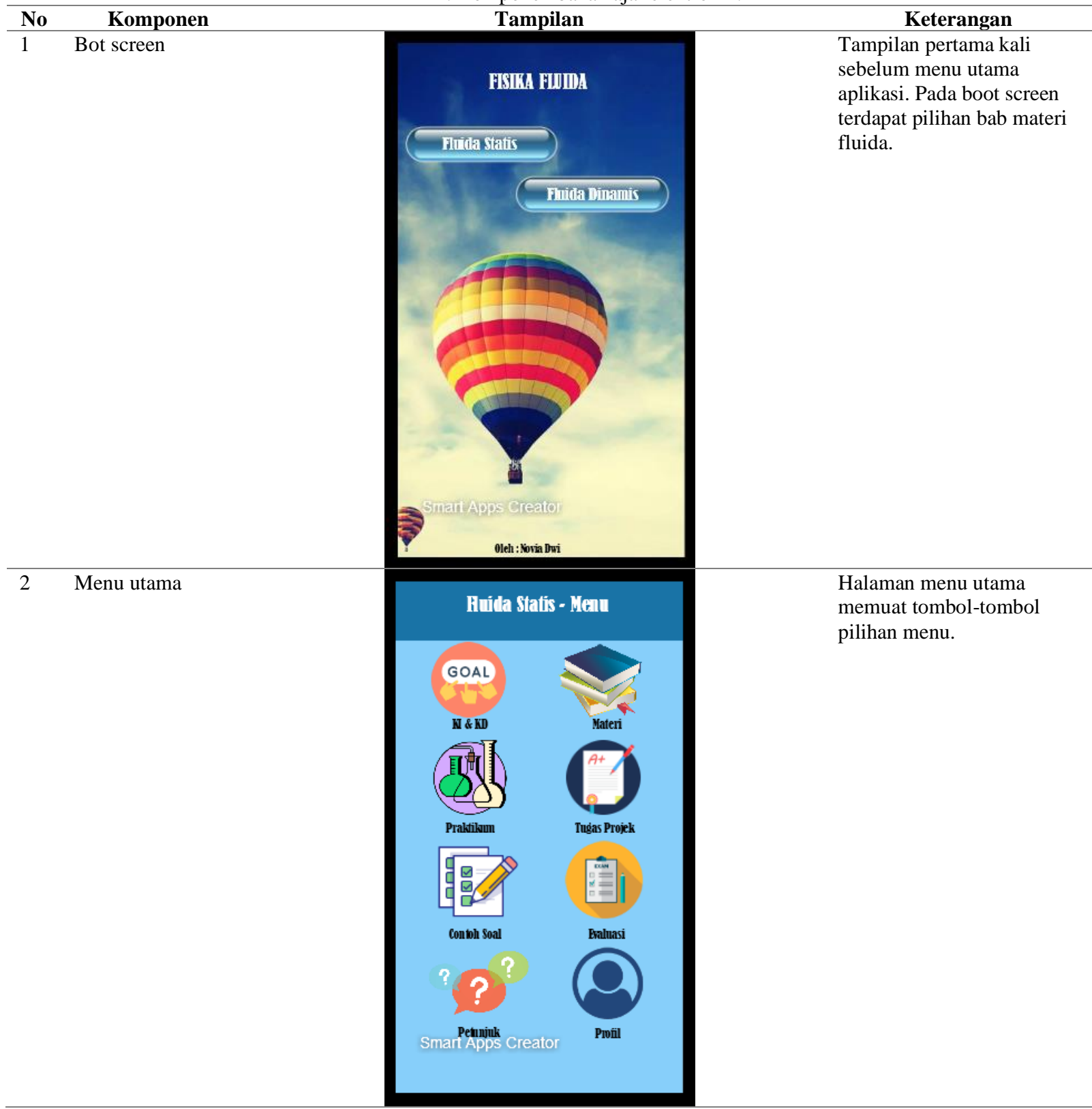




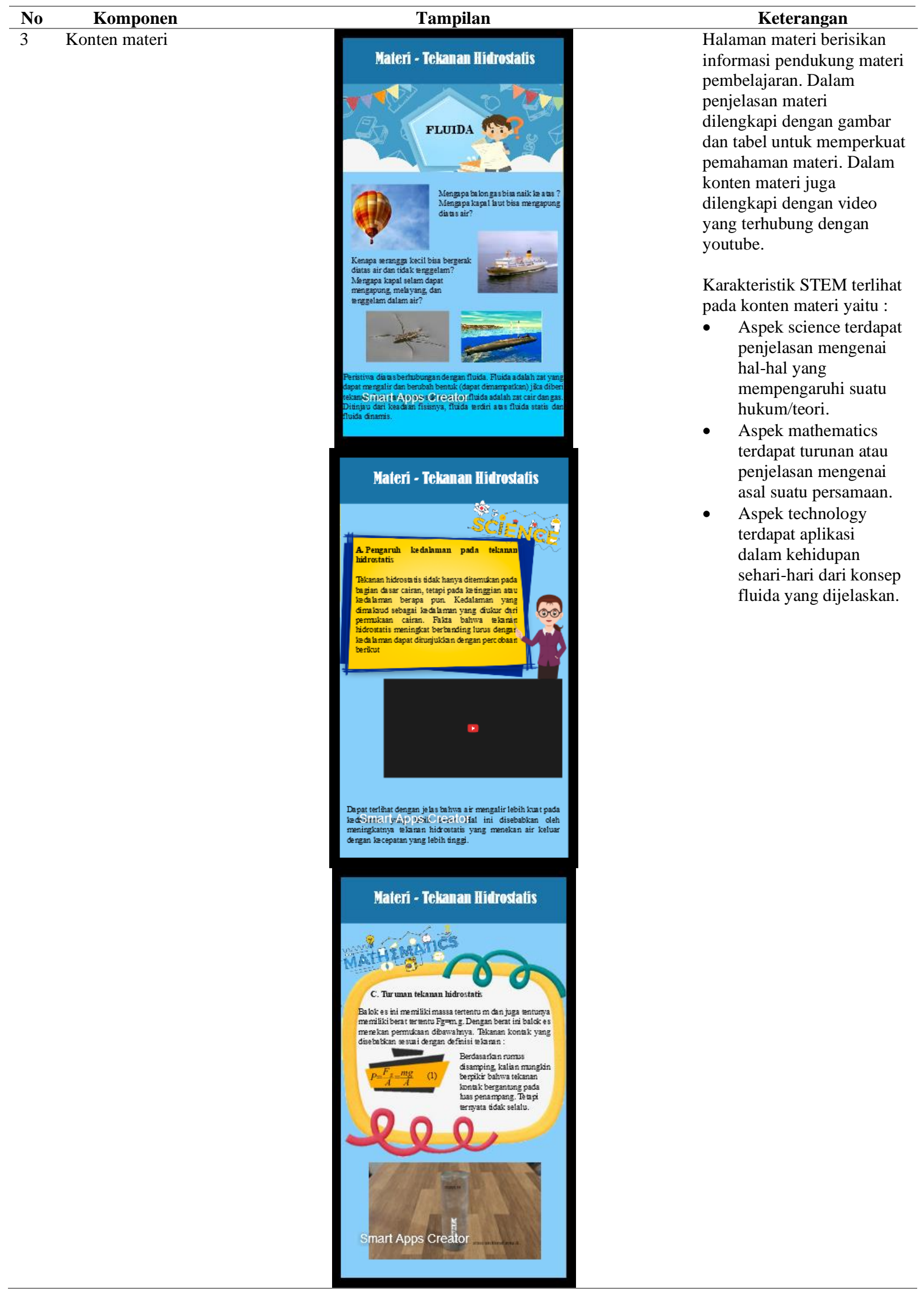




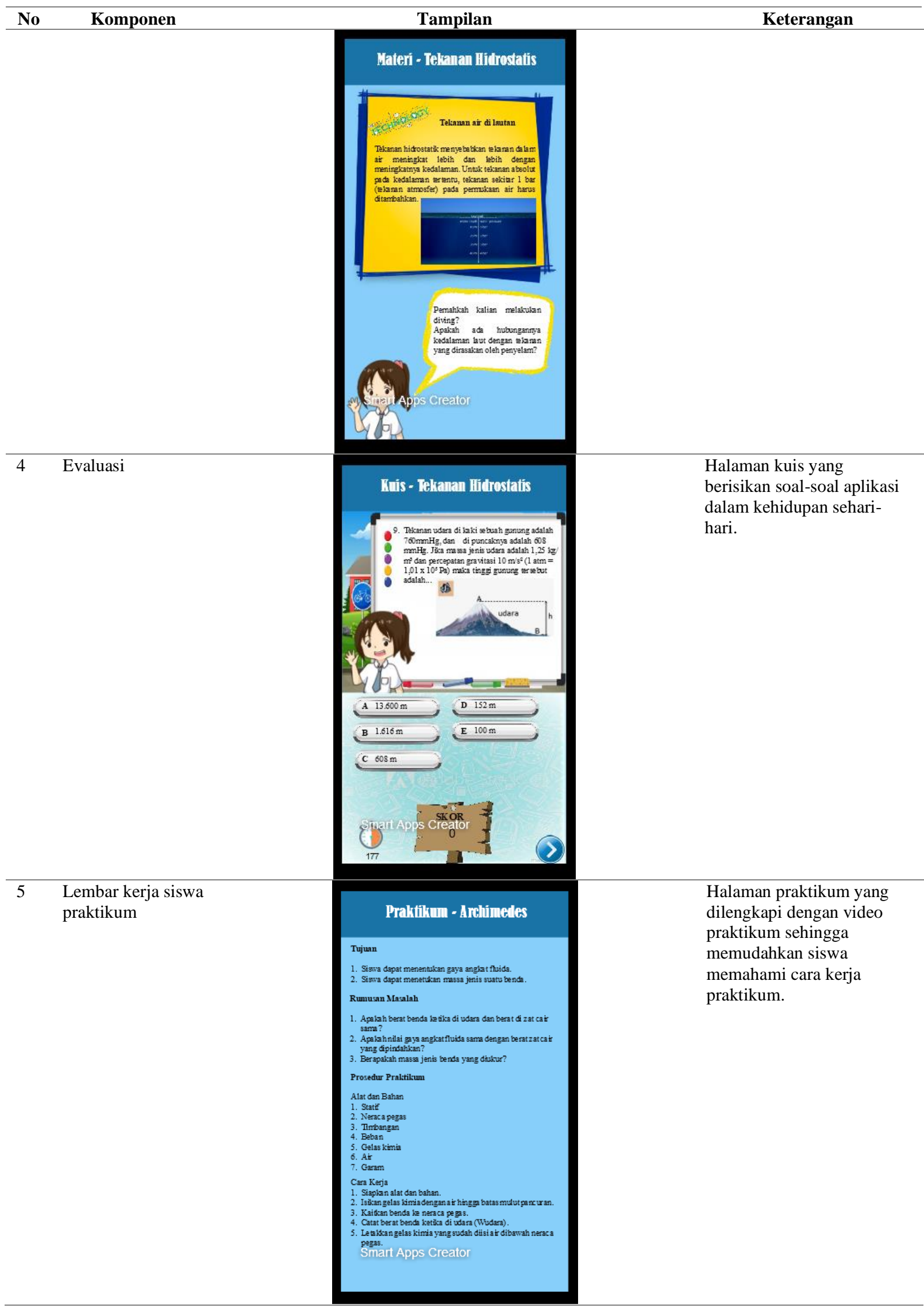




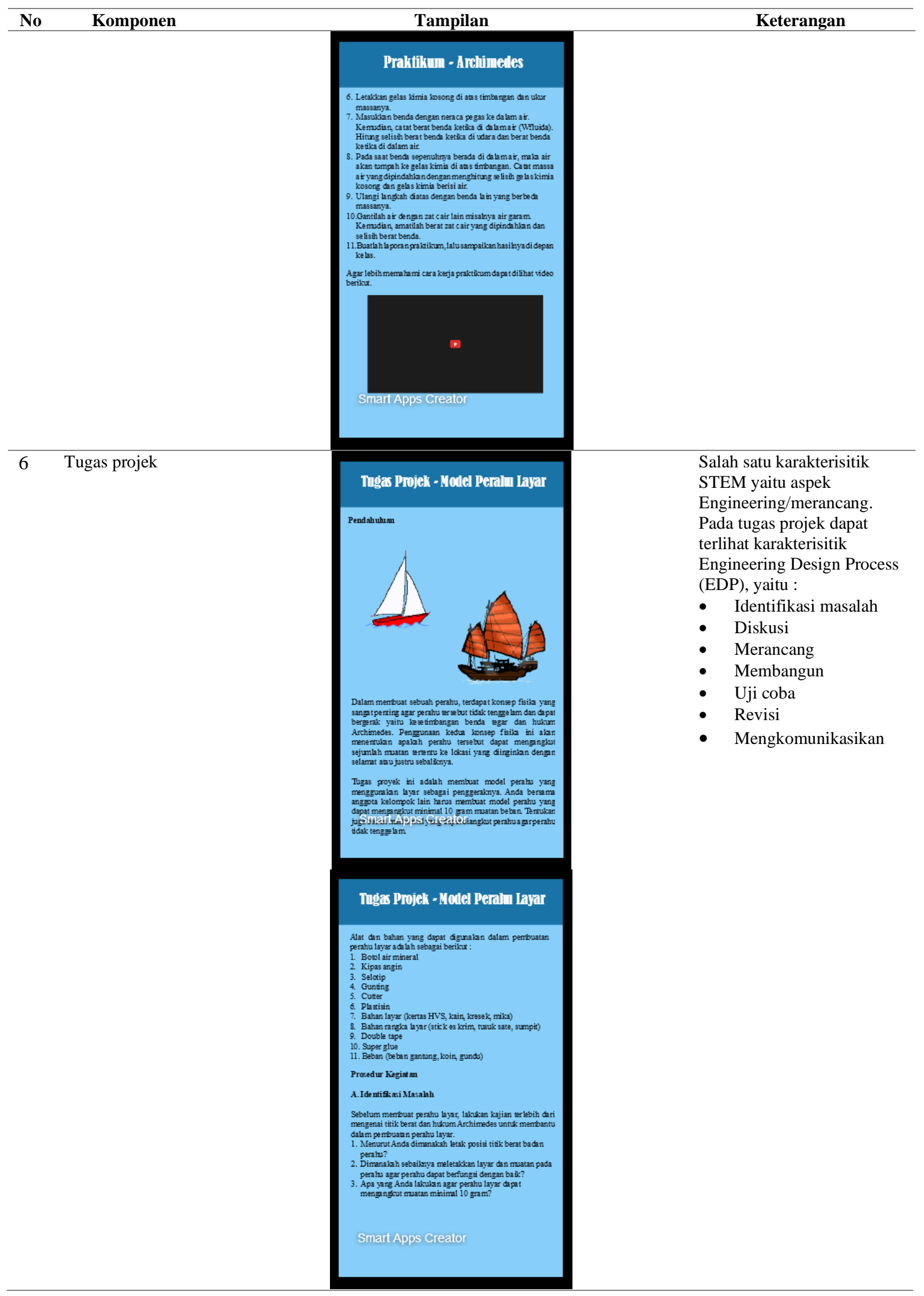




\section{SIMPULAN}

Pada penelitian ini dihasilkan produk berupa bahan ajar elektronik berbasis STEM untuk blended learning pada materi fluida. Bahan ajar elektonik ini dapat menjadi sumber belajar dalam pembelajaran secara tatap muka maupun online yang dapat diakses melalui smartphone. Bahan ajar ini juga dirancang dengan pendekatan STEM untuk mendukung siswa dalam mengembangkan kemampuan seperti menyelesaikan masalah, komunikasi, dan keterampilan kolaborasi.

\section{UCAPAN TERIMAKASIH}

Peneliti mengucapkan terima kasih kepada Ibu Yetti Supriyati dan Bapak Andreas Handjoko P sebagai dosen pembimbing yang telah memberikan banyak masukan dalam penelitian dan juga pada pihak-pihak lain yang membantu peneliti menyelesaikan produk pengembangan bahan ajar elektronik ini.

\section{REFERENSI}

[1] R. Anwar, "Hal-Hal yang Mendasari Penerapan Kurikulum 2013," Jurnal Humaniora, pp. 97-106, 2013.

[2] Sadjati, "Hakikat Bahan Ajar," Jakarta : Universitas Terbuka, 2012.

[3] N. A. Arif, "Konsep Bahan Ajar Elektronik," 2010.

[4] D. Ambarwulan and D. Muliyati, "The Design of Augmented Reality Application as Learning Media Marker-Based for Android Smartphone”, JPPPF (Jurnal Penelitian dan Pengembangan Pendidikan Fisika), vol. 2, no. 1, pp. 73 - 80, Jun. 2016.

[5] P. Sinulingga, T. J. Hartanto, and B. Santoso, "Implementasi Pembelajaran Fisika Berbantuan Media Simulasi PhET untuk Meningkatkan Hasil Belajar Siswa Pada Materi Listrik Dinamis", JPPPF (Jurnal Penelitian dan Pengembangan Pendidikan Fisika), vol. 2, no. 1, pp. 57 - 64, Jun. 2016.

[6] Y. Supriyati, R. Raihanati, and W. Nilawati, "The Development of Horizontal Anchor Items Test Tool by Rasch Model for Physics National Examination using Macromedia Flash”, JPPPF (Jurnal Penelitian dan Pengembangan Pendidikan Fisika), vol. 6, no. 1, pp. 37 - 50, Jun. 2020.

[7] F. I. Dewi, N. A. Wibowo, D. N. Sudjito, and F. Rondonuwu, "The Design of OneDimensional Motion and Two-Dimensional Motion Learning Media Using Digital Camera and Tracker-Based Air Track", JPPPF (Jurnal Penelitian dan Pengembangan Pendidikan Fisika), vol. 6, no. 1, pp. 65 - 74, Jun. 2020.

[8] H. P. Fendi, "Pengembangan Buku Ajar Biologi Berbasis Blended Learning Sebagai Bekal Hidup Di Abad 21 Untuk Mahasiswa S1 Kimia FMIPA UM," Prosiding Seminar Nasional Pendidikan Biologi, pp. 50-61, 2015.

[9] Husamah, "Pembelajaran Bauran," Jakarta : Hasil Pustaka, 2013.

[10] Rahmiyati, Hidayat dan Darmaji, "Pengembangan Modul Elektronik dengan Pendekatan Saintifik Pokok Bahasan Hukum Termodinamika untuk SMA/MA Kelas XI," Jurnal Edufisika, pp 68-81, 2018.

[11] Dewi, Kaniawati dan Suwarma, "Penerapan Pembelajaran Fisika Menggunakan Pendekatan STEM Untuk Meningkatkan Kemampuan Memecahkan Masalah Siswa Pada Materi Listrik Dinamis," Jurnal Quantum : Seminar Nasional Fisika dan Pendidikan Fisika, pp 381-385, 2018.

[12] Krajcik and Delen, "Engaging Learners in STEM Education," Estonian Journal of Education, 2017. 
[13] Chittum dkk, "The Effects of an Afterschool STEM Program on Student's Motivation and Engagement," International Journal of STEM Education, pp 1-6, 2017.

[14] Wu, Deshler and Fuller, "The Effect of Different Versions of a Gateway STEM Course on Student Attitudes and Beliefs," International Journal of STEM Education, pp 1-12, 2018.

[15] I. S. Utami, M. Vitasari, I. Langitasari, I. Sugihartono, and Y. Rahmawati, "The Local Wisdom-Based STEM Worksheet to Enhance the Conceptual Understanding of Pre-service Physics Teacher", JPPPF (Jurnal Penelitian dan Pengembangan Pendidikan Fisika), vol. 6, no. 1, pp. 97 - 104, Jun. 2020.

[16] Yusrizal, "Analysis of Difficulty Level of Physics National Examination's Questions," Jurnal Pendidikan IPA Indonesia, pp 140-149, 2016.

[17] Loverude dkk, "Identifying and Addressing Student Difficulties with Hydrostatic Pressure," American Journal of Physics, pp. 75-78, 2010.

[18] Y. R. Denny, I. S. Utami, S. Rohanah, and D. Muliyati, "The Development of Blended Learning Model using Edmodo to Train Student Critical Thinking Skills on ImpulseMomentum Topic", JPPPF (Jurnal Penelitian dan Pengembangan Pendidikan Fisika), vol. 6, no. 1, pp. 113 - 120, Jun. 2020.

[19] Nada, “ADDIE Model,” American International Journal of Contemporary Research, pp. 68$72,2015$. 
